Available online at: https://proceeding.researchsynergypress.com/index.php/cpmhs/index

RSF Conference Series: Medical and Health Science

e-ISSN (to be processed) / p-ISSN (to be processed)

Volume 1 Number 1 (2021): 60-70

\title{
The Relationship Between Mother's Education Level, Mothers Knowledge and Breastfeeding Status with Toddler Motor Skills and Nutrition Status In Diwek Sub-District, Jombang Regency, East Java, Indonesia
}

\author{
Rahma Rizqiyah $^{1}$, Septa Katmawanti ${ }^{1}$, Erianto Fanani ${ }^{1}$ \\ ${ }^{1}$ FIK, Kesehatan Masyarakat, Indonesia
}

\begin{abstract}
The predominant breastfeeding coverage rate in Jombang Regency is 9 percent, which is the highest in the province of East Java. Furthermore, according to the Jombang Health Profile in 2019, the exclusive breastfeeding rate was 82.9 percent. The exclusive breastfeeding coverage rate is 0.23 percent lower than the rate of 83.03 percent in 2018. Mother's knowledge, mother's education level, environment and family, and socio-cultural support are all factors that contribute to the lack of exclusive breastfeeding. According to several researchers, a mother's level of education and knowledge has the greatest direct influence on breastfeeding. The purpose of this study was to determine the relationship between education level, mother's knowledge, and breastfeeding status with motor skills and nutrition status of toddlers in Diwek District, Jombang. This study used a cross-sectional study design with an observational analytic approach. The total population of this study, which included all children aged 0-4 years in Diwek District, Jombang Regency, was 9,264 children, with 200 samples obtained from calculations using the S. Lemeshow. The findings of this study from three independent variables $(\mathrm{x})$ revealed that only one had a p-value greater than 0.05 or had a significant relationship with toddler motor skills. At the same time, the dependent variable nutritional status demonstrates that all factors in the independent variable have a p-value greater than 0.05 or indicate a link.
\end{abstract}

Keywords: Education Level, mother's knowledge, Breastfeeding Status, toddler's motor skills, and nutrition status

\author{
This is an open access article under the CC-BY-NC license
}

\section{INTRODUCTION}

The basic capital for the generation of quality human beings begins when the baby is in the womb and is accompanied by the provision of breast milk (ASI) from an early age, particularly exclusive breastfeeding. Breast milk contains all of the nutrients that babies require, such as ARA and DHA fatty acids, which function in the production of nerve cell membranes and whose needs can be supplied by exclusive breastfeeding. The majority of the population in Diwek District, Jombang Regency is educated, with 5,759 people, or almost $10.30 \%$, having a higher education level (BPS Jombang, 2018). Diwek District has the second-highest number of highly educated people after Jombang District.

The World Health Organization (WHO) reports that more than 200 million children under the age of five worldwide do not meet the potential for motor development. The majority of them are children from Asia and Africa. Furthermore, according to the results of a national data scale survey conducted by the Ministry of Health of the Republic of Indonesia in 2014, around 13-18\% of children under the age of five in Indonesia experienced growth and development abnormalities (Kemenkes RI, 2017). Exclusive Corresponding author Rahma Rizqiyah, rahmarizqiyah59@gmail.com; Septa Katmawanti, septakatma.fik@um.ac.id 
breastfeeding is one of the factors that influence a child's psychomotor development (Amir et al., 2018). Breastfeeding that is not ideal can also result in malnutrition, malnutrition in newborns, and even death. The rate of population growth will slow as the number of deaths rises (Ainy, 2016). According to Jawa Pos Radar Jombang, the results of the Bulan Timbang conducted in August 2019 revealed a stunting rate in Jombang of 12,013 dispersed throughout all sub-districts at the end of 2019. According to reports, the Diwek Sub-district has the greatest area of any of the 19 sub-districts, with 1,353 toddlers (Radar Jombang, 2019). Furthermore, East Java Province has a stunting rate of $12.2 \%$, which is higher than the national stunting rate of $11.6 \%$ (Kemenkes RI, 2021).

According to the 2019 Health Profile Data for Indonesia, the National Exclusive Breastfeeding Coverage is $67.74 \%$. According to Riskesdas statistics in 2010, exclusive breastfeeding was $11.6 \%$ in East Java. According to Riskesdas (2010), the highest rate of exclusive breastfeeding in mothers with the degree of education - the category never went to school - was $12.4 \%$. Exclusive breastfeeding was $30.2 \%$ according to Riskesdas in 2013; however, according to Riskesdas 2018, the proportion of exclusive breastfeeding was $40.05 \%$, dominant breastfeeding was $1.45 \%$, and partial breastfeeding was $12.0 \%$ (Dinkes, 2018). In Jombang, exclusive breastfeeding coverage is 55\%, predominant breastfeeding coverage is $9 \%$, and partial breastfeeding coverage is 7.5\% (Dinkes Jombang, 2017). The predominant breastfeeding coverage rate in East Java is the greatest. Furthermore, according to the 2019 Jombang Health Profile, the exclusive breastfeeding coverage rate was $82.9 \%$. The rate of exclusive breastfeeding coverage is $0.23 \%$ lower than in 2018 , when it was $83.03 \%$ (Dinkes Jombang, 2019).

Various factors influence children's nutritional status, including the number of children's nutritional status in terms of food intake or frequency, physical activity, and emotional aspects (Winarno., 2020). According to Ogunfowora (2019: 278-283), the mother's breastfeeding pattern can cause 10-18\% of the risk of disease transmission. This is demonstrated by Nigeria's lower newborn mortality rate. Although exclusive nursing reduces the risk of disease transmission, few moms are aware of the benefits of exclusive breastfeeding (Ogunfowora, 2018).

Researchers made preliminary observations by directly asking the midwives on duty at Pustu Bandung in the working area of the Cukir Health Center on Wednesday, September 16, 2020, which revealed that Diwek District is the most populated area in Jombang Regency, with 9,264 infants aged 0-4 years old. The dependent variable component of this study uses two variables, namely nutritional status and motor skills, which distinguishes it from past studies. However, this article only discusses the findings that show an association between variable $\mathrm{x}$ (degree of education, mother's knowledge, and breastfeeding status) and variable y (motor abilities and nutritional status of toddlers).

\section{LITERATURE REVIEW}

Breastfeeding is classified into three types, according to Kemenkes RI (2014): exclusive breastfeeding, dominant breastfeeding, and partial breastfeeding. Predominant breastfeeding occurs when the baby is breastfed but has been given a small amount of water or water-based drinks, such as tea, as food or prelacteal drink before the milk comes out (Kemenkes RI. 2014). Breastfeeding is an activity that provides the finest diet for babies since it contains all of the nutrients that babies require, including ARA and DHA fatty acids. The presence of a protective ability factor and good nutrition in breast milk can provide good nutritional status, reducing child morbidity and mortality. Breast milk contains colostrum, which has 10-17 times the immune-boosting properties of mature milk. Breast milk, according to Warnani (2013: 1-12), is the best and most complete source of nutrition for babies, and it aids in the rapid and healthy development of the baby's brain, nervous system, digestive system, and immune system. 
Furthermore, breast milk (ASI) is the best food for babies because it contains all of the vitamins and nutrients that babies require, especially during the first six months of life (Warnani, 2013: 1-12). Breastfeeding is influenced by a variety of factors, including:

1.According to Septikasari (2018: 9-18), the low level of maternal education indicates that developing human resources through the degree of knowledge is critical for attempts to enhance children's nutritional condition. A mother's education is closely associated with children's nutritional health because the mother is the one who directly cares for her child, including preparing and providing meals.

2.The mother's lack of knowledge is the second reason. The main thing that is highly crucial for the formation of one's actions is knowledge (overt behavior). There are numerous stages of knowledge, including knowing, comprehending, analyzing, and applying. Nutritional status is a state of being caused by the interaction between calorie and protein consumption and physical health.

The following BB/TB indicators are used to assess the nutritional status of toddlers in accordance with PMK No. 2 of 2020 :

Table 1. BB/TB Indicators

\begin{tabular}{cl}
\hline Malnutrition & Z-Score $<-3,0$ \\
\hline Mild Malnutrition & Z-Score $\geq-3,0$ to $<-2,0$ \\
\hline Good nutrition & Z-Score $\geq-2,0$ \\
\hline Over-nutrition & Z-Score $>2,0$ \\
\hline
\end{tabular}

A healthy nutritional status can aid in the process of children's optimal growth and development. Children's growth and development will improve if they are exclusively breastfed for the first four to six months of life. According to Soetjiningsih (2002) in Warnani (2013: 1-12), "development is a growth in skills in increasingly complex body structures and functions, following a regular pattern, as a result of the maturation process." The maturation of the functions of the body organs begins with the ability of the heart to pump blood, the ability to breathe, and the ability to go prone, sit, walk, talk, take objects around them, process emotions, and engage well socially (Warnani, 2013:1-12).

Infants who are not exclusively breastfed have a twofold increased likelihood of having psychomotor development that is below the average than those who are exclusively breastfed. Furthermore, from a cognitive standpoint, exclusive breastfeeding produces the best results for motor development (Al-Rahmad dan Fadillah, 2016: 99-104). To assess toddler motor skills, compare toddler development to the 2016 MCH Handbook on Toddler Development Assessment.

\section{RESEARCH METHODOLOGY}

The research design used was a cross-sectional design in which all variables evaluated, including independent and dependent variables, were measured concurrently (Kemenkes, 2008). This is a quantitative study in which the data generated is in the form of numbers (Ihsanti \& Haryoko, 2020). This study used an analytical observational technique to determine how and why a phenomenon occurs by examining the relationship between causation and effect components. This research data is scaled using an ordinal data scale. The variables in this study were as follows: 
a. The dependent variable was motor skill and nutritional status of toddlers

b. Education level, mother's knowledge, and breastfeeding status were independent variables

In this study, researchers used primary data collected directly from respondents in Diwek District, Jombang Regency. This study was carried out between March and April of 2021. Before the research, the researcher did an ethical test at Poltekkes Kemenkes Malang, with the certificate number Reg.No.: 046/KEPK-POLKESMA/2021. The population in this study included 9.264 infants aged 0-4 years in Diwek District, Jombang Regency, and the sample was selected through non-probability sampling in the form of purposive sampling. The sample determination in this study was acquired from the sample calculation using the S Lemeshow formula, with the probability value received from previous research journals, while the sample determination can be done as follows:

$$
n=\frac{\left\{Z_{1-\alpha} \sqrt{2 \mathrm{P}(1-\mathrm{P})}+Z_{1-\beta} \sqrt{\mathrm{P}_{1}\left(1-\mathrm{P}_{1}\right)+\mathrm{P}_{2}\left(1-\mathrm{P}_{2}\right)}\right\}^{2}}{\left(\mathrm{P}_{1}-\mathrm{P}_{2}\right)^{2}}
$$

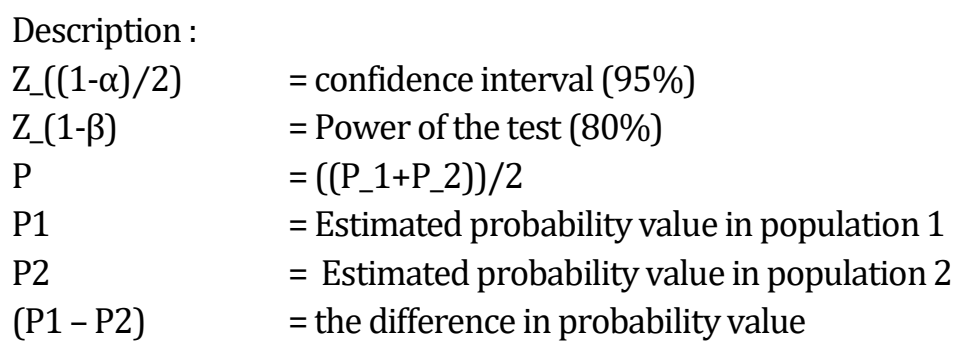

Using the sample size calculation above, the number of participants to be analyzed was 189 infants aged 0-4 years in Diwek District, Jombang Regency. The author then rounded up the sample to 200 mothers of infants and toddlers who had accepted informed consent from the researcher. The inclusion criteria for this study were infants aged 0-4 years with a normal body (not disabled) and mothers with babies aged 0-4 years in Diwek District, Jombang Regency. The age group of 0-4 years old was chosen since it is considered the most vulnerable to infectious diseases (Sholikah, 2017). Babies who were not nurtured by their biological mothers, babies who did not receive breast milk from their biological mothers, and toddlers who lived outside Diwek Subdistrict, Jombang Regency were excluded. Non-test instruments, such as questionnaires and documentation, were applied by researchers in this study. The author designed a questionnaire that included a description of the dependent variable, which was the toddler's motor skills and nutritional status, as well as the independent variables, which were the mother's education level, mother's knowledge, and breastfeeding status. Before being distributed to respondents, the instrument is evaluated for validity and reliability so that it can be used as a collecting data tool. The validity test of the questionnaire at the point of breastfeeding frequency revealed that it was valid because of the value of $r$ count $>r$ table (0.396). Furthermore, the Cronbach's Alpha score of $>0.70$ indicated that the questionnaire reliability test on the variables of knowledge and breastfeeding status was reliable. The researcher applied the 2016 MCH handbook and PMK No. 2 of 2020 to assess toddler motor skills and nutritional status.

The data collection technique used in this study was a questionnaire that fulfilled the instrument's reliability and validity requirements to be sent to mothers with babies aged $0-4$ years and the Observation Guidelines by looking at the motor development abilities of babies aged 0-4 years. The data analysis 
methods used in this study were univariate analysis, bivariate analysis with the Chi-Square test, and multivariate analysis with regression logistic (Binary) test and ordinal regression.

\section{FINDINGS AND DISCUSSION}

Respondents in this study were mothers with children aged 0 to 4 years who were willing to engage in the study. In addition, toddlers aged 0 to 4 years old with a body that is neither disabled nor normal. Data were collected at the Integrated Healthcare Center in the Cukir Health Center's Working Area in Diwek District, Jombang Regency.

\section{Relationship Between Mother's Knowledge and Toddler's Motor Skill in Diwek District, Jombang Regency}

Table 2. Relationship Between Mother's Knowledge and Toddler's Motor Skill

\begin{tabular}{|c|c|c|c|c|c|}
\hline & \multicolumn{4}{|c|}{ Motor Skills in Children } & \multirow[t]{2}{*}{ Asymp. Sig, (2-sided) } \\
\hline & \multicolumn{2}{|c|}{ Poor } & \multicolumn{2}{|c|}{ Good } & \\
\hline Mother's Knowledge & $\mathbf{n}$ & $\%$ & $\mathbf{n}$ & $\%$ & 0,002 \\
\hline Poor & 2 & 1,0 & 5 & 2,5 & \\
\hline Moderate & 16 & 8,0 & 136 & 68,0 & \\
\hline Good & 13 & 6,5 & 28 & 14,0 & \\
\hline Total & 31 & 15,5 & 169 & 84,5 & \\
\hline
\end{tabular}

Based on the results of the table above, it is known that mothers with poor knowledge have children with poor motor skills in as many as two people or $1.0 \%$. Meanwhile, 16 people, or $8.0 \%$, of women with moderate knowledge have children with poor toddler motor skills. 13 people, or $6.5 \%$, are knowledgeable mothers with children who have good motor skills. As many as five people, or $2.5 \%$, have children with good motor skills despite their mothers' lack of knowledge. Toddlers with good motor skills born to mothers with moderate knowledge accounted for 136 kids or $68.0 \%$ of the total. Meanwhile, mothers with good knowledge have children with good motor skills in as many as 28 people (14.0\%). In the Pearson Chi-Square test, the Asymp. value Sig. (2-sided) is 0.002. As the basis for decision making, the Asymp. Sig. (2-sided) value of $0.002<0.05$ implies that Ho is rejected and Ha is accepted.

According to the statistical test table results of the association between the mother's knowledge level and the motor skills of toddlers in Diwek District, Jombang Regency, 136 women out of 200 respondents, or $68.0 \%$, had children with good motor skills and a moderate level of knowledge. The chisquare test results yielded a value $=0.002$; therefore, Ho is rejected, and Ha is accepted, indicating that there is a relationship between the mother's degree of education and the motor skills of toddlers in Diwek District, Jombang Regency. The definition of knowledge itself is the result of the human senses or the consequence of knowing someone about an object by feeling results such as sight, smell, and hearing. Several factors can influence a person's knowledge, including the level of education of the mother, 
economic status, and the surrounding environment (Muchid, 2012). Knowledge of the advantages of exclusive breastfeeding and the components of breast milk, one of which is colostrum (Windiyati, 2019).

The level of knowledge a mother has in Maternal Role Attainment (MRA) nursing theory is a factor that can affect and interact directly with individuals (Adelia, 2018). Furthermore, the mother's level of knowledge is included in the microsystem layer, which is the major layer of elements influencing the toddler's output, in this case, gross motor skills. The better the mother's knowledge or awareness, the better the development of the toddler (Warnani, 2013), (Intani et al., 2019).

This study's findings are consistent with other research that found a link between a mother's degree of education and her toddler's motor abilities, such as "Hubungan Tingkat Pendidikan dan Pengetahuan Ibu Terhadap Perkembangan Bayi (0-12 Bulan) di Kota Bandung." According to the p-value $=0.01$ of the study, as many as 49 mothers had a high level of knowledge about having a developing baby (Fauziah, 2018). Furthermore, according to Muchid's study, "Hubungan Pengetahuan Ibu Dengan Perkembangan Motorik Kasar Anak Usia 3-4 Tahun di Posyandu Budi Lestari Desa Tlogorejo Guntur Demak," as many as 10 out of 32 moms with children aged 3-4 years show normal gross motor development with p-value = 0.028 (Muchid, 2012). Based on the findings of the research, theory, and prior studies, it is possible to conclude that the mother's level of knowledge has a significant relationship with the motor skills of toddlers in Diwek District, Jombang Regency.

\section{Relationship between Mother's Education Level and Toddler's Nutritional Status in Diwek District, Jombang Regency}

Table 3. Relationship between Mother's Education Level and Toddler's Nutritional Status

\begin{tabular}{|c|c|c|c|c|c|c|c|c|c|}
\hline \multirow[b]{3}{*}{$\begin{array}{l}\text { Mother's } \\
\text { Education }\end{array}$} & \multicolumn{8}{|c|}{ Toddler's Nutritional Status } & \multirow{3}{*}{$\begin{array}{c}\text { Asymp. Sig, } \\
\text { (2-sided) }\end{array}$} \\
\hline & \multicolumn{2}{|c|}{ Malnutrition } & \multicolumn{2}{|c|}{$\begin{array}{c}\text { Mild } \\
\text { Malnutrition }\end{array}$} & \multicolumn{2}{|c|}{ Good } & \multicolumn{2}{|c|}{ Over } & \\
\hline & $\mathbf{n}$ & $\%$ & $\mathbf{n}$ & $\%$ & $\mathbf{n}$ & $\%$ & $\mathbf{n}$ & $\%$ & \\
\hline Low & 5 & 2,5 & 9 & 4,5 & 29 & 14,5 & 4 & 2,0 & 0,021 \\
\hline High & 6 & 3,0 & 13 & 6,5 & 127 & 63,5 & 7 & 3,5 & \\
\hline Total & 11 & 5,5 & 22 & 11,0 & 156 & 78,0 & 11 & 5,5 & \\
\hline
\end{tabular}

Based on the results of the table above, it is known that as many as five people, or $2.5 \%$, of children under the age of five born to mothers with low levels of education had malnutrition status. The proportion of children under the age of five born to low-education moms who have mild malnutritional status is nine individuals or $4.5 \%$. Twenty-nine people, or $14.5 \%$, of mothers with low education had children under the age of five who have a good nutritional status. The proportion of children under the age of five born to loweducation moms who had toddlers with over-nutrition status is four people or $2.0 \%$. Meanwhile, six people, or 3.0\%, of mothers with higher education have children with malnutrition status. As many as 13 people, or $6.5 \%$, are mothers with a higher education who have children with mild malnutritional status. There are 127 toddlers (63.5\%) with highly educated mothers who had toddlers with good nutritional status. As many as seven people, or 3.5\%, had higher-educated mothers who have toddlers with over- 
nutrition status. In the Pearson Chi-Square test, the Asymp Sig (2-sided) value is 0.021 . Based on the findings of Asymp Sig ( 2 -sided) $0.021<0.05$, it is possible to deduce that Ho is rejected and Ha is approved.

The stage of education level that has been determined based on a person's degree of development, goals to be reached, and abilities to be cultivated is referred to as the education level. Food consumption in children, mother's education, mother's knowledge, parenting style, and economic challenges are all factors that influence toddler nutritional status (Nurmaliza \& Herlina, 2019). The level of education has a significant impact on a person's ability to understand and receive information. The level of education has a significant impact on a person's ability to understand and receive information. Increasing human resources through increased knowledge is critical in the attempt to enhance children's nutritional status. Mothers' education is intimately associated with children's nutritional health since mothers directly care for children, including preparing and providing meals for them. The level of education of mothers in Diwek District, Jombang Regency is defined as higher education, i.e. from junior high school to university (PT) (Miftakhul Jannah \& Maesaroh, 2020).

The findings of this study are consistent with research from Nurmaliza (2019) titled "Hubungan Pengetahuan dan Pendidikan Ibu Terhadap Status Gizi Balita," which shows that as many as 30 mothers from 44 respondents with higher education have toddlers with good nutritional status, or 73.2 percent with a p-value $=0.034$, indicating that there is a significant relationship between the mother's education and the toddler's nutritional status (Nurmaliza \& Herlina, 2019). Furthermore, according to a Yerni (2021) study titled "Hubungan Antara Faktor Ibu dengan Status Gizi Balita di Puskesmas Hinai Kiri Kecamatan Secanggang Kabupaten Langkat Tahun 2020," as many as 27 mothers from 54 highly educated respondents who have children with good nutritional status were obtained (Yerni \& Sihombing, 2021). So, based on the findings of the research, theory, and previous studies, it is concluded that there is a significant correlation between the level of education of mothers and the nutritional status of children under the age of five in Diwek District, Jombang Regency.

Relationship Between Mother's Knowledge and Toddler's Nutritional Status in Diwek District, Jombang Regency

Table 4. Relationship Between Mother's Knowledge and Toddler's Nutritional Status

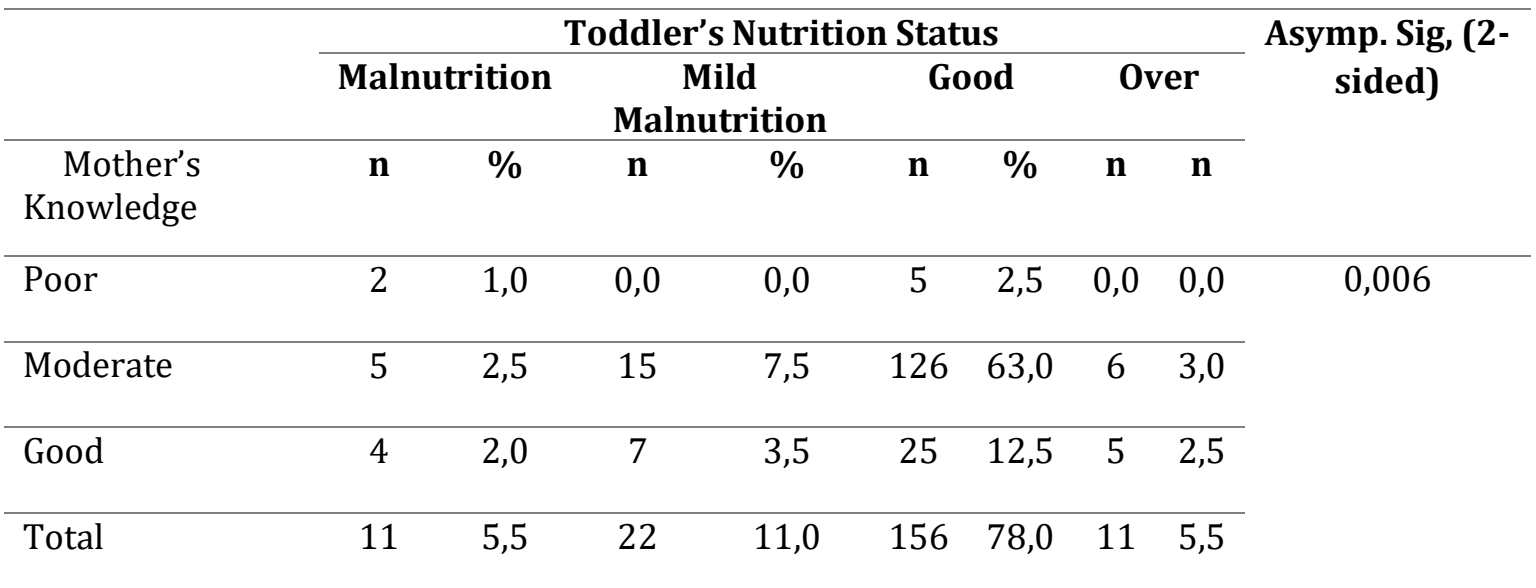

According to the findings of statistical tests, 126 women out of 200 total responses, or 63\%, were knowledgeable about parenting children with high nutritional status. The p-value is 0.006 , thus Ho is 
rejected, and Ha is accepted, indicating that there is a significant association between mother's education level and child motor skills in Diwek District, Jombang Regency. The definition of knowledge is the result of human senses of items such as sight, smell, and hearing. Several factors influence a person's knowledge, including their level of education, financial status, and the environment in which they live (Muchid, 2012).

The level of knowledge a mother has in Maternal Role Attainment (MRA) nursing theory is a factor that can influence and interact directly with individuals. Furthermore, the mother's level of knowledge is included in the microsystem layer, which is the major layer of factor that influences toddler output, in this case, the nutritional status of toddlers. Knowledge is the most crucial domain for action formulation. Knowledge is related to the mother's level of education, with the assumption that someone with a greater level of education will likewise have more knowledge. In this scenario, the population in Diwek District, Jombang Regency is of a higher education level, ranging from junior high school to university (PT). As a result, the greater the mother's knowledge, the better her toddler's nutritional state (Umar \& Puspita, 2017).

This study's findings are consistent with Windiyati's (2019) study, "Hubungan Pengetahuan dan Pola Asuh Terhadap Status Gizi Balita di Posyandu Tunas Melati Desa Limbung Kecamatan Sungai Raya Kabupaten Kubu Raya." According to the study, the mother's knowledge of good nutrition before counseling was lower than the mother's knowledge of good nutrition after counseling, indicating that counseling helped increase the mother's knowledge of nutrition at Posyandu Tunas Melati. Because providing counseling means providing education to mothers about toddler nutrition and balanced nutritional intake, it can have an impact on positive behavior changes to improve the nutritional status of toddlers with $\mathrm{p}$-value $=0.00$, mother's knowledge can influence a mother's behavior to be better (Windiyati, 2019).

Furthermore, according to the findings of a Yuneta (2019) study titled "Hubungan Antara Tingkat Pengetahuan Ibu Dengan Status Gizi Balita di Kelurahan Wonorejo Kabupaten Karanganyar," as many as 33 out of 50 respondents, or $66 \%$ of mothers with knowledge, had children with good nutritional status. As revealed by the $p$-value $=0.00$, mothers with good knowledge will realize the importance of good nutritional status for the health and welfare of their toddlers (Nurma Yuneta, 2019). So, based on the findings of this study, theory, and prior research, it is possible to conclude that there is a significant correlation between mothers' level of knowledge and the nutritional status of children under the age of five in Diwek District, Jombang Regency.

\section{Relationship Between Breastfeeding Status and Toddler's Nutritional Status}

Table 5. Relationship Between Breastfeeding Status and Toddler's Nutritional Status

\begin{tabular}{|c|c|c|c|c|c|c|c|c|c|}
\hline \multirow[b]{3}{*}{$\begin{array}{l}\text { Breastfeeding } \\
\text { Frequency }\end{array}$} & \multicolumn{8}{|c|}{ Toddler's Nutritional Status } & \multirow{3}{*}{$\begin{array}{c}\text { Asymp.Sig, } \\
\text { (2-sided) }\end{array}$} \\
\hline & \multicolumn{2}{|c|}{ Malnutrition } & \multicolumn{2}{|c|}{$\begin{array}{c}\text { Mild } \\
\text { Malnutrition }\end{array}$} & \multicolumn{2}{|c|}{ Good } & \multicolumn{2}{|c|}{ Over } & \\
\hline & $\mathbf{n}$ & $\%$ & $\mathbf{n}$ & $\%$ & $\mathbf{n}$ & $\%$ & $\mathbf{n}$ & $\%$ & \\
\hline Never & 4 & 2,0 & 0 & 0 & 13 & 6,5 & 3 & 1,5 & 0,002 \\
\hline Occasionally & 3 & 1,5 & 7 & 3,5 & 80 & 40,0 & 3 & 1,5 & \\
\hline
\end{tabular}


RSF Conference Series: Medical and Health Science, Vol. 1 (1), 60-70

The Relationship Between Mother's Education Level, Mothers Knowledge and Breastfeeding Status with Toddler Motor Skills and Nutrition Status In Diwek Sub-District, Jombang Regency, East Java, Indonesia Rahma Rizqiyah, Septa Katmawanti, Erianto Fanani

\begin{tabular}{lcccccccc}
\hline Frequently & 4 & 2,0 & 15 & 7,5 & 63 & 31,5 & 5 & 2,5 \\
\hline Total & 11 & 5,5 & 22 & 11,0 & 156 & 78,0 & 11 & 5,5
\end{tabular}

According to the findings of statistical tests on the association between breastfeeding status and nutritional status of children under the age of five, 80 of the 200 total respondents, or $40.0 \%$, of mothers with a high frequency of breastfeeding had children with good nutritional status. When the p-value is equal to 0.002 , Ho is rejected, and Ha is approved. As a result, it can be concluded that there is a significant correlation between breastfeeding status and the nutritional status of children under the age of five. Breastfeeding to toddlers is influenced by a variety of factors, including the mother's degree of education, environmental support, mother's knowledge, and mother's income (Umami \& Margawati, 2018). The frequency of breastfeeding is also explained as the factor that most influences the individual (in this case, the mother) and is located in the main layer or microsystem layer on the output of toddlers themselves, in this case, the nutritional status of toddlers, in the theory of Maternal Role Attainment (MRA) nursing. Furthermore, genetics, hormones, and a lack of physical exercise can all have an impact on toddlers' nutritional status (Chaterina et al., 2019).

The results of this study are consistent with the findings of Suharmanto's (2020) study, "Hubungan Pemberian ASI Eksklusif dengan Status Gizi Balita," which found that as many as 60 mothers out of 85 samples provided optimal breastfeeding to have children with normal nutritional status, with a p-value of 0.00 . Babies who were not exclusively breastfed were twice as likely to have stunting at the age of 6-12 years as infants who were exclusively breastfed. Furthermore, the significance value of the data processing results achieved a value of 0.029 , the value of the odds ratio is 7.034 , which suggests that the risk is seven times higher in children aged 1-5 years experiencing malnutrition, according to the results of research from Andriani (2015). Because some mothers decided to give formula milk and other nutrition to babies under six months of age, the majority of respondents did not give exclusive breastfeeding. Sixty percent of mothers do not exclusively breastfeed. Maximum breastfeeding will improve children's nutritional status (Alia et al., 2019). So, based on the findings of this study, theory, and prior research, it is possible to conclude that there is a significant correlation between breastfeeding status and toddlers in Diwek District, Jombang Regency.

\section{CONCLUSION AND FURTHER RESEARCH}

Based on the preceding reasoning, it is possible to conclude that:

1. There is a relationship between mothers' knowledge and toddler's motor skills in Diwek District, Jombang Regency.

2. In Diwek District, Jombang Regency, there is a relationship between the mother's educational level and the nutritional status of children under the age of five.

3. There is a relationship between mothers' knowledge and the nutritional status of children under the age of five in Diwek District, Jombang Regency.

4. In Diwek District, Jombang Regency, there is a relationship between breastfeeding and the nutritional status of children under the age of five.

Based on the findings of this study and the constraints of the researchers mentioned above, there are various suggestions for future researchers to consider, including: 
1. Future researchers can look into aspects other than education level, mother's knowledge, and breastfeeding status that can affect motor skills.

2. It is expected that additional study would be conducted in the Integrated Healthcare Center in the Work Area of the Cukir Health Center, a total of 11 Integrated Healthcare Centers.

\section{REFERENCES}

Adelia, D. D. (2018). Hubungan Tingkat Pengetahuan dan Peran Orang Tua Dengan Perkembangan Motorik Kasar Dan Motorik Halus Pada Anak Usia 4-5 Tahun Di Tk Istiqomah Lowokwaru Kota Malang. 31-39.

Ainy, H., Nurrochmah, S., \& Katmawanti, S. (2016). Hubungan antara fertilitas, mortalitas, dan migrasi dengan laju pertumbuhan penduduk. Jurnal Preventia, 2, 2-9.

Al-Rahmad, A. H., \& Fadillah, I. (2016). Perkembangan Psikomotorik Bayi 6 - 9 Bulan berdasarkan Pemberian ASI Eksklusif. AcTion: Aceh Nutrition Journal, 1(2), 99. https://doi.org/10.30867/action.v1i2.18

Alia, S., Ali, H. I., Zoubeidi, T., \& Ahmed, M. (2019). Nutrition Knowledge and Satisfaction Levels of Postbariatric Surgery Adults in the United Arab Emirates: A Pilot Study. Journal of Nutrition and Metabolism, 2019. https://doi.org/10.1155/2019/9148459

Amir, A., Nursalim, N., \& Widyansyah, A. (2018). Faktor-Faktor Yang Mempengaruhi Pemberian Asi Pada Bayi Neonatal Di Rsia Pertiwi Makassar. Media Gizi Pangan, 25(1), 47. https://doi.org/10.32382/mgp.v25i1.59

Chaterina, R., Cahyaning, D., \& Negeri, U. (2019). Hubungan Pola Konsumsi , Aktivitas Fisik dan Jumlah Uang Saku dengan Status Gizi pada Siswa SMP Negeri di Kota Malang Tahun 2019. 1(1), 22-27.

Dinkes. (2017). Profil Kesehatan Kabupaten Jombang Tahun 2017. Dinas Kesehatan Kabupaten Jombang, 82-88.

Dinkes. (2018). Hasil Utama Riset Kesehatan Dasar Jawa Timur 2018. Jakarta: Badan Penelitian Dan Pengembangan Kesehatan, Kementrian Kesehatan Republik Indonesia, 1-82.

Dinkes Jombang. (2019). Profil Kesehatan Kabupaten Jombang 2019. Profil Kesehatan Kabupaten Jombang 2019, 53(9), 1689-1699.

Fauziah, N., Tanuwidjaja, S., \& Yunus, A. (2018). Hubungan Tingkat Pendidikan dan Pengetahuan Ibu Terhadap Perkembangan Bayi ( 0 - 12 Bulan ) di Kota Bandung The Relationships Between Levels Of Education And Knowledge Of Mothers To Infant Development ( 0 - 12 Month ) In Bandung City Nika Fauziah , 2 Suga. Prosiding Pendidikan Dokter, 01(2), 178-186.

Ihsanti, F. N., \& Haryoko. (2020). Survei Daya Tahan VO 2 max Peserta Ekstrakurikuler Bolavoli di Sekolah Menengah Pertama ( SMP ). Sport Science and Health, 2(12), 613-619. http://journal2.um.ac.id/index.php/jfik/article/view/12092/6964

Intani, T. M., Syafrita, Y., \& Chundrayetti, E. (2019). Hubungan Pemberian ASI Eksklusif dan Stimulasi Psikososial dengan Perkembangan Bayi Berumur 6-12 Bulan. Jurnal Kesehatan Andalas, 8(1S), 7. https://doi.org/10.25077/jka.v8i1s.920

Kemenkes, P., \& Jurusan, S. (2008). BREASTFEEDING SELF EFFICACY DAPAT MENINGKATKAN PRODUKSI ASI PADA IBU POST PARTUM Lutfiana Puspita Sari, Lusinta Agustina. 114-120.

Kemenkes RI. Pusat Data dan Informasi Situasi dan Analisis ASI Eksklusif. (2014). Kementrian Kesehatan Replubik Indonesia. 
Kemenkes RI. (2021). Laporan Kinerja Kementerian Kesehatan Tahun 2020. In Laporan Akuntabilitas Kinerja Tahun 2020.

Malang, U. N., No, J. S., \& Timur, J. (2020). Hubungan Aktivitas Fisik dan Pola Makan Terhadap Status Obesitas Pada Siswa Sekolah Menengah Pertama. 2(6), 301-311.

Miftakhul Jannah, \& Maesaroh, S. (2020). HUBUNGAN TINGKAT PENDIDIKAN IBU DENGAN STATUS GIZI BALITA DI POSYANDU BANGUNSARI SEMIN GUNUNG KIDUL TAHUN 2014. 42-52. https://raharja.ac.id/2020/10/13/literature-review/

Muchid, A., Samiasih, A., \& Mariyam. (2012). Hubungan Pengetahuan Ibu Dengan Perkembangan Motorik Kasar Anak Usia 3-4 Tahun Di Posyandu Budi Lestari Desa Tlogorejo Guntur Demak. Hubungan Pengetahuan Ibu Dengan Perkembangan Motorik Kasar Anak Usia 3-4 Tahun Di Posyandu Budi Lestari Desa Tlogorejo Guntur Demak, 6(1), 36-43.

Nurmaliza, \& Herlina, S. (2019). HUBUNGAN PENGETAHUAN DAN PENDIDIKAN IBU TERHADAP STATUS GIZI BALITA. Jurnal Kesmas Asclepius, 1(2), 106-115.

Ogunfowora, O. B., \& , Tinuade Adetutu Ogunlesi , Abiodun Folashade Adekanmbi , Victor Ayodeji AyeniReport, C. S. (2018). Does Infant Feeding Method Influence the Incidence and Pattern of Morbidities among Human Immunodeficiency Virus-exposed Uninfected Nigerian Infants? Indian Journal of Public Health, 62(3), 2018-2020. https://doi.org/10.4103/ijph.IJPH

Sholikah, A., Rustiana, E. R., \& Yuniastuti, A. (2017). Faktor - Faktor yang Berhubungan dengan Status Gizi Balita di Pedesaan dan Perkotaan. Public Health Perspective Journal, 2(1), 9-18.

Umami, W., \& Margawati, A. (2018). Faktor Yang Mempengaruhi Pemberian ASI. Jurnal Kedokteran Diponegoro, 7(4), 1720-1730.

Warnani, A. I. (2013). Pengaruh penyapihan anak usia (1-6 bulan) terhadap pertumbuhan di kelurahan sragen kulon kecamatan sragen kabupaten sragen naskah publikasi.

Windiyati. (2019). HUBUNGAN PENGETAHUAN DAN POLA ASUH IBU TERHADAP STATUS GIZI BALITA DI POSYANDU TUNAS MELATI DESA LIMBUNG KECAMATAN SUNGAI RAYA KABUPATEN KUBU RAYA TAHUN 2019. Jurnal Kebidanan, 9(2), 428-436.

Yerni, A., \& Sihombing, S. (2021). HUBUNGAN ANTARA FAKTOR IBU DENGAN STATUS GIZI BALITA DI PUSKESMAS HINAI KIRI KECAMATAN SECANGGANG KABUPATEN LANGKAT TAHUN 2020. Jurnal Ilmiah Kebidanan, 7(1), 67-73. 